\title{
The geographical results of the Tibet Mission
}

\section{Sir Frank Younghusband K.C.I.E.}

To cite this article: Sir Frank Younghusband K.C.I.E. (1905) The geographical results of the Tibet Mission, Scottish Geographical Magazine, 21:5, 229-245, DOI: 10.1080/00369220508733559

To link to this article: http://dx.doi.org/10.1080/00369220508733559

册Published online: 27 Feb 2008.

Submit your article to this journal $\pi$

LII Article views: 9

Q View related articles $\sqsubset$ 


\title{
THE SCOTTISH
}

\section{GEOGR A P H I C A L}

\author{
MAGAZINE.
}

\section{THE GEOGRAPHICAL RESULTS OF THE TIBET MISSION. ${ }^{1}$}

By Sir Frank Youngmusband, K.C.I.E.

(With Illustrations.)

Though I shall tell to-night of a journey to the "Forbidden City," there is, I fear, little, strictly speaking, new that I shall have to say. $\mathrm{My}$ companions and myself were, indeed, the first Europeans to enter Lhasa for many years. Still, we cannot claim credit for having been the first of all, and all $I$ can do is to corroborate and emphasise the work of former travellers, and especially of those hardy Indian explorers A-K, Sarat Chandra Das, and others, who had made such careful surveys and interesting notes, that some at least of our obstacles were removed.

Such corroboration is, however, very necessary, for an impression had of recent years grown up in Europe that Tibet was a wretched, poor, inhospitable country; and this is not what those few travellers, European and Indian, who had been to Lhasa before had described, nor is it actually the case. The northern part of Tibet, which is all that recent European travellers have seen, is indeed barren, uncultivated, and worthless, and this forms quite two-thirds of the whole. But Tibet is a large country - as large as the provinces of Bombay, Madras, and the Punjab put together, and there is a third part still remaining which is remarkably well cultivated, which is dotted over with thriving villages and the well-built and comfortable residences of the Tibet gentry. Taking it as a whole, then, and excluding the worthless desert portion, Tibet is probably fully as rich as Kashmir or Nepal. The valleys in which Lhasa, Gyantse, and Shigatse are situated, and the valley of the Brahmaputra, are neither barren plateaux nor yet narrow

1 An Address delivered before the Society ou March 8th. Published by permission of the Royal Geographical Society.

VOL. XXI. 
V-shaped gorges. They are flat valleys from four or five to as much as ten miles broad, covered with good soil, well irrigated and richly cultivated. This is the most important geographical fact which, though mentioned casually by former travellers, we were able to re-establish and confirm.

And with this fact clearly impressed upon your minds, let me now ask you to follow in the footsteps of the Tibet Mission in its journey from India to Lhasa. We unfortunately had to take our bodies there, and for the human body Tibet and Sikkim, through which we had to pass on the way into Tibet, are at certain seasons anything but attractive. You, however, need go there in mind only, and for the mind I do not know, in the whole realm of nature, any greater glories than Sikkim and Tibet afford. At the very outset of our travels was the sight which in all the world I consider the supreme-the view of Kinchenjunga from Darjiling, described by many travellers before, but by none better than by Mr. Douglas Freshfield in his recent book on this region. We had then to pass through as superb tropical forests as are anywhere to be met with, and, emerging on the high Tibetan tableland, it was our good fortune to live for. a month in full view of the magnificent panorama of 150 miles of the highest peaks in the Himalayas, with the loftiest mountain in the world as the culminating object. Lastly, we had ever before us in the dim mysterious distance the Sacred City, of which so little was known, and entrance to which was barred by every obstacle which man and nature could raise; and while my military companions had constantly to think of how best to overcome the resistance we might encounter, we of the political service had continually with us the earnest desire and the ambition to lessen by all our powers of reasoning and persuasion the military resistance, and above all so to impress the people who were now first making our acquaintance, that on our departure their disposition towards us should be one of friendliness rather than hostility, and that they should no longer look upon us as people to be roughly and rigidly excluded, but, on the contrary, respected and welcomed.

What more inspiring task could any men be intrusted with? And while this is not the place to speak of the military and political work of the Mission, I may at least say that our objects were attained, and I may express my firm conviction that from this time onwards all European travellers will be the gainers for what the British Mission to Lhasa did in 1904. One only evil geographical result I foresee. This Society will have one less destination for the adventurous explorers of Great Britain, and the Sven Hedins of the future, like a fast-expiring race, will be driven back and back till they finally vanish from the Earth amid the Arctic snows. But for this misfortune not we only are to blame, but also and chiefly one of your own Gold Medalists, the great Viceroy of India to whose initiative the whole enterprise was due, and without whose constant support it could scarcely have been brought to a conclusion so disastrous for future explorers.

Our start from Darjiling in June 1903 wis miserable enough. The monsoon was just bursting, the rain was coming down in cataracts, and all was shrouded in the densest mist. Few knew of the enterprise upon 
which I was embarking, but a little knot of strangers who had assembled in the porch of the hotel had got an inkling, and shouted "Good luck" as I rode off, covered with waterproofs, into the mist to join my companions, Mr. White and Captain O'Connor, in Sikkim. And detestable though the rain was, there was still a large surplus of joy in riding through those wonderful Sikkim forests, day after day seeing fresh marvels of forest growth or flowery beauty. The mountain-sides were everywhere a wealth of tropical vegetation, rich and luxuriant. And here under the shades of the mighty giants of the forest grew the stately tree-ferns, often 40 or 50 feet in height, with fronds 10 or 12 feet long. All were in bright fresh foliage, and besides ferns of every graceful form and of the subtlest delicacy of tracery were variegated coloured plants, like calladiums, and closely connecting all together, and festooned from tree to tree, were creepers of every size, from the great elephant creeper whose leaves resembled elephants' ears, to light trailing vine-like tendrils lightly strung from bough to bough; while here and there, as some bright surprise, the eye would light upon the most perfect orchid, or other flowery marvel, which brought one to a halt in an ecstasy of enjoyment. Nor should I omit to mention the brilliant butterflies glinting past on every side. Seventeen different kinds did I count in the space of 200 yards in the Teesta valley; and in few other places in the world are to be found such a variety of rare butterflies, so many different orchids, and such a wealth of trees and flowers as in Sikkim. There are, I believe, over six hundred different orchids alone to be found here, and over sixty separate kinds of rhododendron.

Fain would I dwell longer on the attractions of this wonderful country, but it is with Tibet itself that we are chiefly concerned to-night, and thither I must without delay transport you. Just cross one pass, and all is changed. On the far side of the Kongra-lama pass not a tree is to be seen. If in some secluded nook a plant a foot high is met with, it is a curiosity. In place of the deep-cut valleys of Sikkim there are great plains ten or twelve miles wide. The sky is cloudless, and the view extended over many and many a mile. Here at Khamba Jong Mr. White had laid out a camp, and here we spent many delightful months, doing our best to bring to reason a people nearly as obstinate as ourselves, and between whiles making roving expeditions to distant valleys, geological investigations with Mr. Hayden of the Geological Survey, botanical trips with Dr. Prain of the Botanical Gardens in Calcutta, natural history expeditions with Captain Walton, I.M.S.; every day and every hour enjoying the charming summer climate, and, above all, the unrivalled panorama of the mighty Himalayas at the very culminating point of their grandeur, where all the loftiest peaks in the world were majestically arrayed before us. Captain Ryder, known to you for his journey in China, surveyed and measured all this wonderful region, and will, I trust, before long give yon full particulars of his surveys. But who will ever be able to adequately describe the fascination of that glorious range of mountains? From sunrise to sunset the days were a continual delight. As I looked out of my tent in the early morning, while all below was still wrapped in a steely grey, far away in the 
distance the first streaks of dawn would be just gilding the snowy summits of Mount Everest, poised high in heaven as the spotless pinnacle of the world. By degrees the whole great snowy range would be illuminated and shine out in dazzling, unsullied whiteness. Then through all the day it would be bathed in ever-varying hues of blue and purple till the setting sun clothed all in a final intensity of glory, and left one hungering for daylight to appear again.

And all was rendered doubly interesting from the history of its geological past, which Mr. Hayden was able to describe to me. He was indeed enraptured with the district from the geological standpoint, and a bed of fossil oysters he discovered there had more fascination for him than Lhasa itself. He was able, from the oysters, to accurately determine the age of the hills in this part of Tibet. According to him they were "recent," that is to say, not more than two or three million years old, and the main axis of the Himalayas was thoroughly modern, perhaps not more than a few hundreds of thousands of years old. In what to geologists are really ancient times Tibet was below a sea which washed around the base of the Himalayas-a mighty granite ridge which is constantly being protruded upward from the interior of the earth, and ever being worn away by the snowfall on its summit. Never have I been able to see Nature at work on such a mighty scale as here, and when the scientific results of Mr. Hayden's work in this region have been thoroughly investigated, I feel sure they will prove of the highest interest and value.

The Mission remained at Khamba Jong from July 7 to December 6, but long before the latter date we had discovered that our political objects would never be obtained until we advanced further into the country. A move on to Gyantse was accordingly ordered, and as a considerable body of troops, under the command of General Macdonald, was to escort the Mission, the line of advance was changed on to the Chumbi route.

Winter was now on us, and the difficulties which General Macdonald and his troops had to contend with can hardly be realised in England. But not even the rigours of a Tibetan winter were able to stop the advance of the little force of British and Indian troops.

Early in December we crossed the Jelap-la and descended into the Chumbi valley. At Yatung, the trade mart established under the old convention, a wall had some years ago been erected to exclude our trade, and beyond this our traders had so far never been allowed to pass. As we debouched on a bright frosty morning from the pine forest in which we had encamped for the night, we saw this wall built right across the road and high up the mountain-side on either hand. Whether we should have to fight our way through, or whether the Tibetan general would respond to the arguments I had used the previous day and gracefully allow us through, had yet to be proved, and General Macdonald used every military precaution. But, to our relief, we saw the great door in the tower standing open, and we were soon passing peaceably through the gate of Tibet, never, I hope, to be closed against us again. 
We then emerged on to the main Chumbi valley, which, though not wide and open like the valleys we afterwards saw in Tibet Proper, is decidedly less steep and narrow than the Sikkim valley. Both in the valley-bottom and on the hillsides there was room enough for comfortable

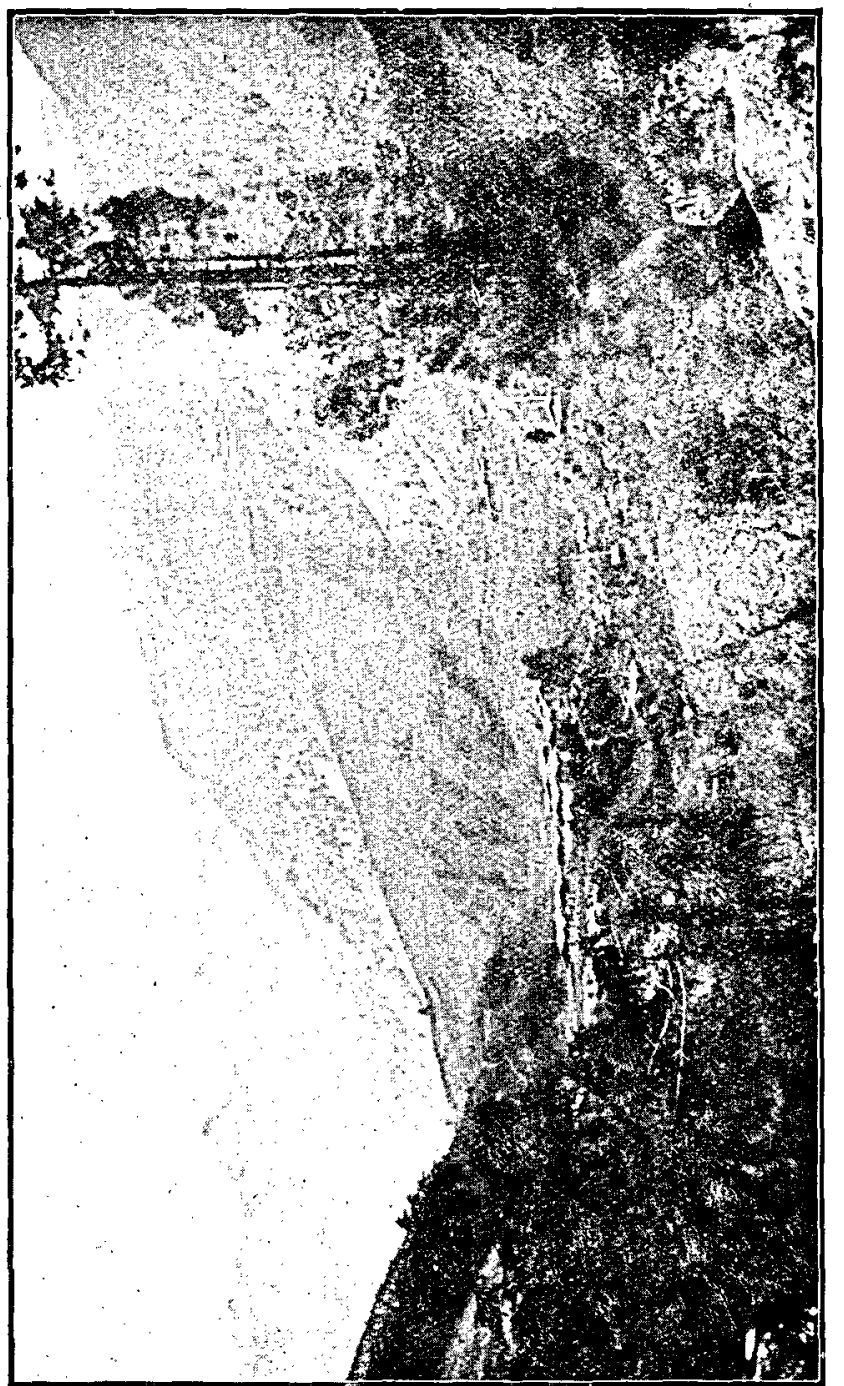

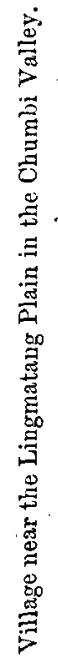

villages and cultivated fields. The people were very well-to-do, and, what was more satisfactory from our point of view, decidedly well disposed. They soon showed themselves to be keen traders, and must have made large fortunes out of us during last year. They are not true Tibetans, but are called Tomos. Nor is their valley, which is on the 
Indian side of the watershed, considered a part of Tibet Proper, which is looked upon as extending only as far as the mouths of steep gorges we a few days later passed through in the upper part of the valley. The rainfall is only about half that of Darjiling, and the climate in general much superior.

The Mission remained three weeks in Lower Chumbi, while military preparations for a further advance were being made; and then in the very depth of winter, on Tanuary 8 , we crossed the Tang-la, 15,200 feet high, on to the Tibetan plateau again. Never shall I forget that day. Reveille sounded at the first streak of dawn, and as I looked out of my tent the very spirit of Frost seemed to have settled on the scene. The stars were shooting out sharp clean rays from the clear steely sky. Behind the great rugged peak of Chumalhari the first beams of dawn were showing out, but with no force yet to cheer or warm, and only sufficient light to make the cold more apparent. Buckets of water were, of course, frozen solid. The remains of last night's dinner were a hard solid mass. The poor Sikhs were just crawling out of their tents, so shrivelled with the cold it looked as though, if they shrivelled much more, there would be nothing left of them. The thermometer stood at $18^{\circ}$ below zero, or just $50^{\circ}$ of frost, and though this is not considered much in Canada and Siberia, and I dare say those who have just returned from the Antarctic would consider it pleasantly warm, I should remind you that $50^{\circ}$ of frost at a height of 15,000 feet above sea-level is a very different thing from $50^{\circ}$ of frost on the sea-level. At 15,000 feet, where the effort of breathing is a continual drain upon one's strength, the mere weight of the heavy clothes one has to wear in cold weather is a sufficient strain in itself. Any additional effort exhausts one immediately. And if it tries us Europeans, who are more or less inured to cold, how much more distressing must it be to the natives of India! and that they were able to march fifteen miles across the pass that day, and spend the rest of the winter, as they had to, immediately on the other side, at a height of but little under 15,000 feet, is, I think, a striking testimony to their powers of endurance and the high spirit which prevails among them. Colonel Hogge and the 23rd Pioneers most willingly faced this ordeal, and by this act of endurance proved once and for all to the Tibetans that their country was no longer inaccessible to us, even in the depth of winter.

Here at Tuna more fruitless parley with the Tibetans ensued. They paid one or two visits to me, and once I rode over with Captains O'Connor and Sawyer to see them amid their own surroundings, to gauge their capacity, and to estimate the strength and direction of the various influences at work among them. It became sufficiently evident to us that the real control of affairs was in the hands of the Lhasa lamas, three of whom, one from each of the three great monasteries at Lhasa, were present on the occasion. The four generals whom we then met were amiable and polite enough. They repeated by rote the formula, "Go back to the frontier." But the impetus to obstruct came from the three lamas, who, with scowls on their faces, remained seated on the ground, showing not the slightest signs of civility or ordinary 
politeness, and instigating the generals to detain us in the Tibetan camp till we would name a definite date for withdrawal. When I think of their rabid fanatical obstruction on that occasion, and compare it with the almost cordial reception we subsequently had in all the great monasteries and in the most sacred shrines before we left Lhasa, I cannot help feeling that we went a long way towards breaking down that barrier of exclusion which, set up by the lamas for their own selfish ends, has kept away from us a people who, when left to themselves, showed every inclination to be on friendly terms with us and indulge their natural instinct for trading.

But parleying with the Tibetans occupied only an insignificant part of my time at Tuna, and I had ample leisure to enjoy the magnificent natural scenery around us. Immediately before us was an almost level and perfectly smooth gravel plain, which gave a sense of space and freedom, and on the far side of the plain, ten or twelve miles distant, rose the superb range of mountains which forms the main axis of the Himalayas and the boundary between Tibet and Bhutan. They were an unceasing joy to me, and the sight of them alone was ample reward for all the hardships we had to endure. The sun would strike our tents at about seven in the morning. The sky would generally then be cloudless save for a long soft wisp of gauze-like haze, and perhaps a few delicate streaks of pink or golden cloud poised motionless on the horizon. And the great snowy mountains, in the early morning when I used to go out and watch them, instead of being sharp, clear, and cold, would be veiled in that blue, hazy, dreamy indistinctness which makes the view of Kinchenjunga from Darjiling so marvellously beautiful, and the hard stern mountains as ethereal as fairyland. The bare brown of the base of the mountains was toned down into exquisite shades of purple and pink, while the white of the snowy summits shaded softly into the cerulean of the sky above. On the plain, plump little larks and finches would be scurrying about in search of food. Now and then a little vole would be seen basking in the sun at the mouth of his hole. And over all there reigned a sense of peace and quiet, which made it hard to believe that only ten miles off, five of the highest lamas in Tibet were solemnly cursing us and publishing to the people round threats of attack upon our camp.

Nor was every day, nor the whole of each day, of this same peaceful nature. Almost invariably at ten or eleven a terrific wind would arise and blow with fury for the rest of the day. Mighty masses of cloud would come sweeping up from the direction of India. Snow would sometimes fall, and then for two or three days together we would be the sport of a terrific blizzard. The mountains would be hidden, and nothing would be visible but dull masses of fiercely driven snow, as fine and dry as dust, and penetrating everywhere. For days together the thermometer would not rise above $15^{\circ}$, even in the middle of the day. Our camp would be the very picture of desolation. It seemed impossible that the poor sentries at night would ever be able to stand against the howling storm and the penetrating snow, or that our soldiers would ever be able to resist an attack from the Tibetans under such terrific circumstances. 
Then one morning we would find the snow-clouds had passed away from over us, and see the great peak Chumalhari emerging calm, strong, and irresistible from out of the mass of cloud still tossing wildly round its base. Below all seemed chaos. It was difficult to stand against the

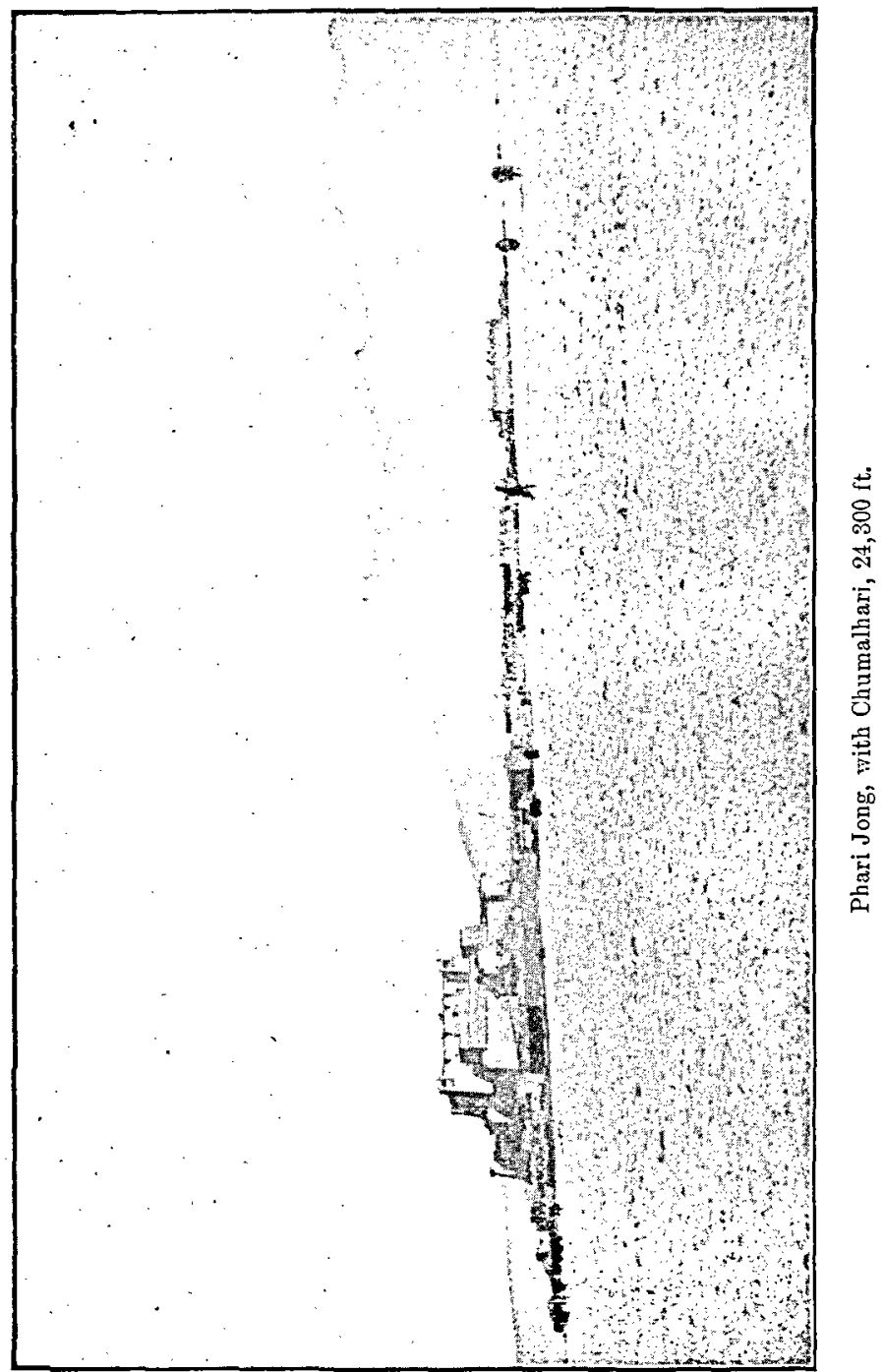

driving wind; the dust and the powdery snow were still battling furiously around one and around the base of the mountain, and the birds were driven hither and thither. But towering above all the tumult below, serene and majestic, and looking prouder, loftier, and purer than ever, rose the great peak reverenced even by the unimaginative 
Tibetans; and above it lay the calm blue sky, illimitable in its restfulness and light-a sky of bright and liquid azure, through which one seemed able to pierce right into heaven itself.

Throughout January, February, and March the bitter winds continued, often accompanied by snow in blinding blizzards, through which the convoys and their escort had to force their way with perhaps even greater sufferings than fell to us. But gradually, as week by week went by, the temperature rose. The military preparations in rear were completed by General Macdonald, and early in April we marched down to Gyantse. Of the military incidents on the way I will say nothing. It was the deepest disappointment to me that fighting should have been necessitated, and the Tibetan generals were as little anxious for it as I was, but they had impossible orders from Lhasa-orders not to fight, not to negotiate, and not to let us proceed. Unless, therefore, we were prepared to abandon the whole object of the Mission, fighting was inevitable.

Arrived at Gyantse on April 11, we found a flat open valley five or six miles wide, dotted all over with flourishing hamlets and intersected by numerons water-channels. Round each hamlet, along the waterchannels, and by the bed of the river were willow and poplar trees just showing signs of bursting into foliage. The banks were covered with masses of iris plants, which later on were to flower out into sheets of purple. The piercing cold of the Tuna uplands was left behind. There was only a slight touch of frost at night, while the days were beautifully fine and bright; and we were looking forward to a restful summer of peaceful negotiation, when suddenly ominous clouds began to collect around us, and early on the morning of May 5 we were awakened by wild shouts and firing, and, looking out of our tents, saw Tibetans firing into us through a wall only ten yards off. How Major Murray and his Gurkhas warded off the attack; how Colonel Brander defended the post for nearly two months against the Tibetans, who had now invested us; and how General Macdonald eventually returned with a relieving force, drove back the Tibetans, and captured the jong, has been told elsewhere. Geographically, the important point is that the refusal of the Tibetans to negotiate at Gyantse necessitated our advance to Lhasa. On July 14 we set out, much impeded by heavy rain, and soon set aside the delusion that Tibet is a rainless country. Well on till September we had frequent rain, and the size of the rivers and side streams was quite sufficient evidence that this part of Tibet receivesprobably up the Brahmaputra valley-a quite considerable rainfall, say between 20 and 30 inches, at a rough guess.

We crossed the easy Karo-la Pass, about 16,000 feet, where Colonel Brander had fought his gallant little action early in May, and the next day debouched on to the most lovely lake I have ever seen-the Yamdok Tso. In shape it was like a rough ring, surrounding what is practically an island; and in colour it varied to every shade of violet and turquoise blue and green. At times it would be the blue of heaven, reflecting the intense Tibetan sky. Then, as some cloud passed over it, or as, marching along, we beheld it at some different angle, it would 
flash back rays of the deep greeny blue of a turquoise. Anon it would show out in various shades of richest violet. Often, when overhead all was black with heavy rain-clouds, we would see a streak of brilliant light and colour flashing from the far horizon of the lake; while beyond

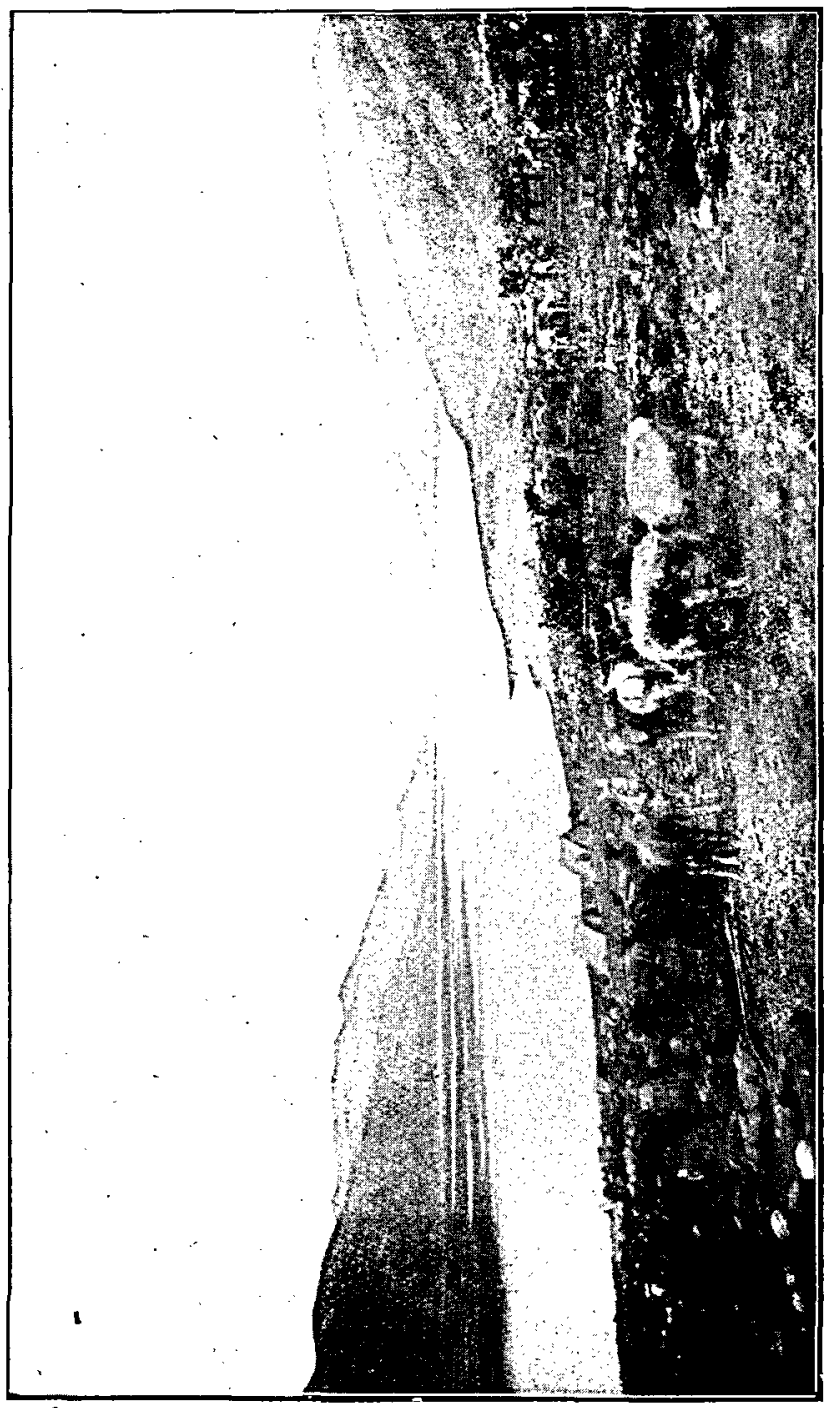

告

it and beyond the bordering mountains, each receding range of which was of one more beautiful shade of purple than the last, rose once more the mighty axial range of the Himalayas, at that great distance not harsh in their whitey coldness, but softly tinted with a delicate blue, and shading away into the exquisite azure of the sky. What caused the 
marvellous colouring of this lake, which even the Tibetans call the turquoise lake, we could none of us say. Perhaps it was its depth, perhaps it was its saline character, or some chemical component of its water. But whatever the main cause, one cause at least must have been the intensity of clearness in the liquid Tibetan sky, so deep and so translucent that even the sky of Greece and Italy would look pale and thick beside it.

For three days we marched along the shores of this beautiful lake, and then we ascended our last pass and looked down on to the Brahmaputra river, and almost upon Lhasa itself. But the sacred city.was still left hid. Masses of mountains in range after range were all we could see in that direction, and General Macdonald had still the very serions obstacle of the Brahmaputra river, now in almost its full flood, to overcome before we could reach our goal. The Brahmaputra we found to be divided into numerous channels, but we were able to cross it at a spot where it narrowed to 200 yards, though not without the loss by drowning of the one officer to whom, of all others in the force, our success in reaching Lhasa was due-Major G. H. Bretherton, the chief supply and transport officer. The river rushed in whirling vortices past a cliff, from which Captain Sheppard, R.E., suspended a wire rope to the opposite side, and upon it rigged up a flying ferry. The river valley was from three to five miles wide, and, like the Gyantse valley, richly cultivated with wheat and barley, dotted over with hamlets, monasteries, well-built and comfortable residences of the great men of the country, and with pleasant groves of poplar, walnut, and even a few peach and apricot trees. The side valleys were also well cultivated, and the hillsides, though bare of trees, were covered with grass, which should afford excellent pasturage for many more sheep and goats than we actually saw there. It was altogether a smiling prospect, and doubts as to the possibility of being able to suppiy our troops with the necessaries of life, for the year round if required, were at once removed.

I was now met by a variety of deputations, each one of increasing weight and importance, and each more urgent than the last in begging me not to proceed to Lhasa. The Dalai Lama himself even wrote to me-an act of unprecedented condescension on his part; and he sent his High Chamberlain to say that if we went to Lhasa, his religion would be spoilt and he would die. I had to inform him, in reply, of the delicate and painful position in which $I$ was placed, for if, on the one hand, I went on to Lhasa, I understood that His Holiness would die, while if I stayed where I was I would myself die, as I would undoubtedly have my head cut off if I failed to obey the orders I had received and negotiate the treaty in Lhasa itself. Reluctant as I was to cause the premature demise of the Dalai Lama, I felt I had no alternative, I informed the High Chamberlain, but to proceed to Lhasa.

Expectation was now at its height. Fach corner we turned we felt sure we should see Lhasa. We hastened to the top of one rise after another in the hopes of catching the first glimpse. The advance patrols 
of mounted infantry, on their return, were eagerly questioned. At length, on August 2, we rounded our last corner and saw the golden roofs of the Potala of Lhasa glittering in the distance, and on the following day encamped beneath its walls.

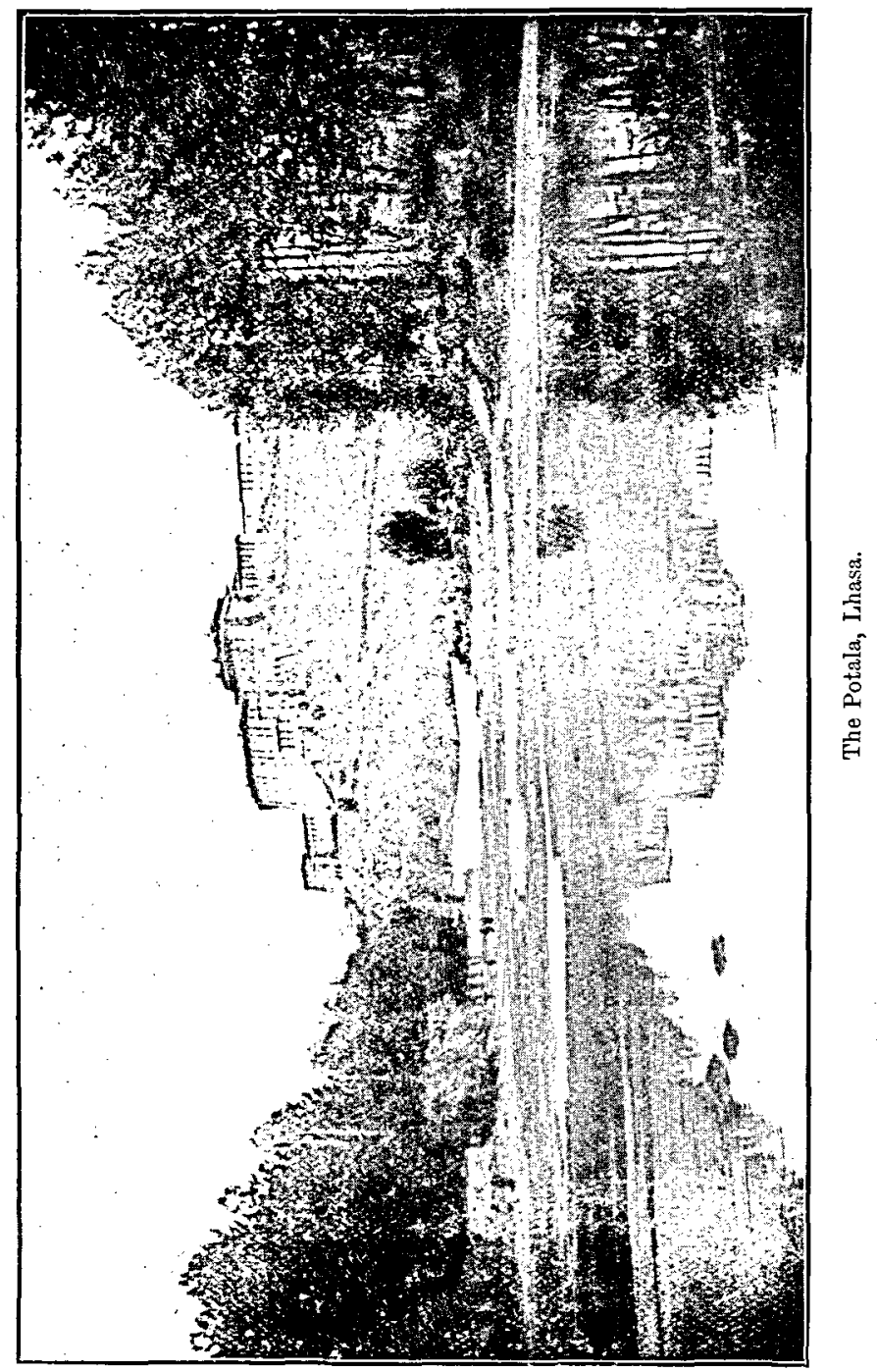

Here in a lovely valley covered with trees, rich with cultivation, and watered by a river as broad as the Thames at Westminster, here hidden away by range after range of snowy mountains, lay the mysterious Forbidden City, which no living European had seen before. To many who had supposed, because it was so secluded, it must be a kind of 
dreamland city, it was, I dare say, disappointing, for it was after all built by men, and not by fairies. Its streets were not paved with gold, nor were its doors of pearls. The streets were, indeed, horribly muddy, and the inhabitants less like fairies than any I have so far seen.

But the Potala, the palace of the Grand Lama, was an imposing, massive structure, very solidly built of masonry, and picturesquely perched on a rocky eminence dominating the whole plain and the city at its base. Numbers of the houses in the city were, too, well built and solid, and often surrounded by shady trees. The rock-perched palace and the strange city at its base would be striking anywhere, but set in this beautiful valley, deep in the very heart of the mountains, they gathered an additional impressiveness which all who saw them recognised.

It was, however, more to the inhabitants than to their buildings that I had to devote my chief attention during my stay in Lhasa. All the leading men, both lay and ecclesiastical, here came before me, and with them I reasoned and argued and chaffered day after day and week after week. Appallingly ignorant and inconceivably unbusinesslike they were. No one man had supreme authority or full responsibility to negotiate with me. A council were supposed to be the chief executive authorities, but they could do nothing without the consent of the National Assembly, and they, without any presiding officer to control them, or any sense of responsibility, simply censured instead of endorsing what the Executive Council did, while these latter were prohibited from attending meetings of the National Assembly to argue their case in person. A more hopelessly inept organisation for dealing with a crisis in their foreign affairs it would be difficult to imagine. But ignorant, bigoted, and apparently immovable as they were, they had their good points. They were almost invariably polite, and they were genial. The humblest little joke was enough to set them off laughing, and $I$ do not recall separating at the close of a single interview of all the many we had at Lhasa with any feeling of ill temper. I must confess to a feeling of exasperation sometimes when I reflected that my convention had to be got through in so short a time, and no ray of daylight was for so long visible through the dreary clouds of obstruction; but these poor Tibetans do deserve credit for never having really irritated me. It was, after all, their business to make as good a bargain as they could with me, and pertinacity is a trait which need not be cavilled at: Still, it was heavy, weary work. Eight or ten of them would come together. Each one had to have his say, so that when he returned home he could boast that he had for his part spoken up to the British Commissioner. Each one I listened to patiently, and each one I answered. In this way, as every day produced a few fresh men, I worked through most of the leading men in Lhasa, while Captain O'Connor, whose trials were still greater than mine, tackled even larger numbers in his private room.

On the whole, I formed a low estimate of their mental calibre. It is impossible to regard them as much else than children. My talks with them were not only about the business in hand, but about general affairs 
and about religion. The Ti Rimpochi, with whom the Dalai Lama left his seal in his flight for Lhasa a few days before our arrival, held the chair of divinity in the Gaden monastery, and was universally rever-

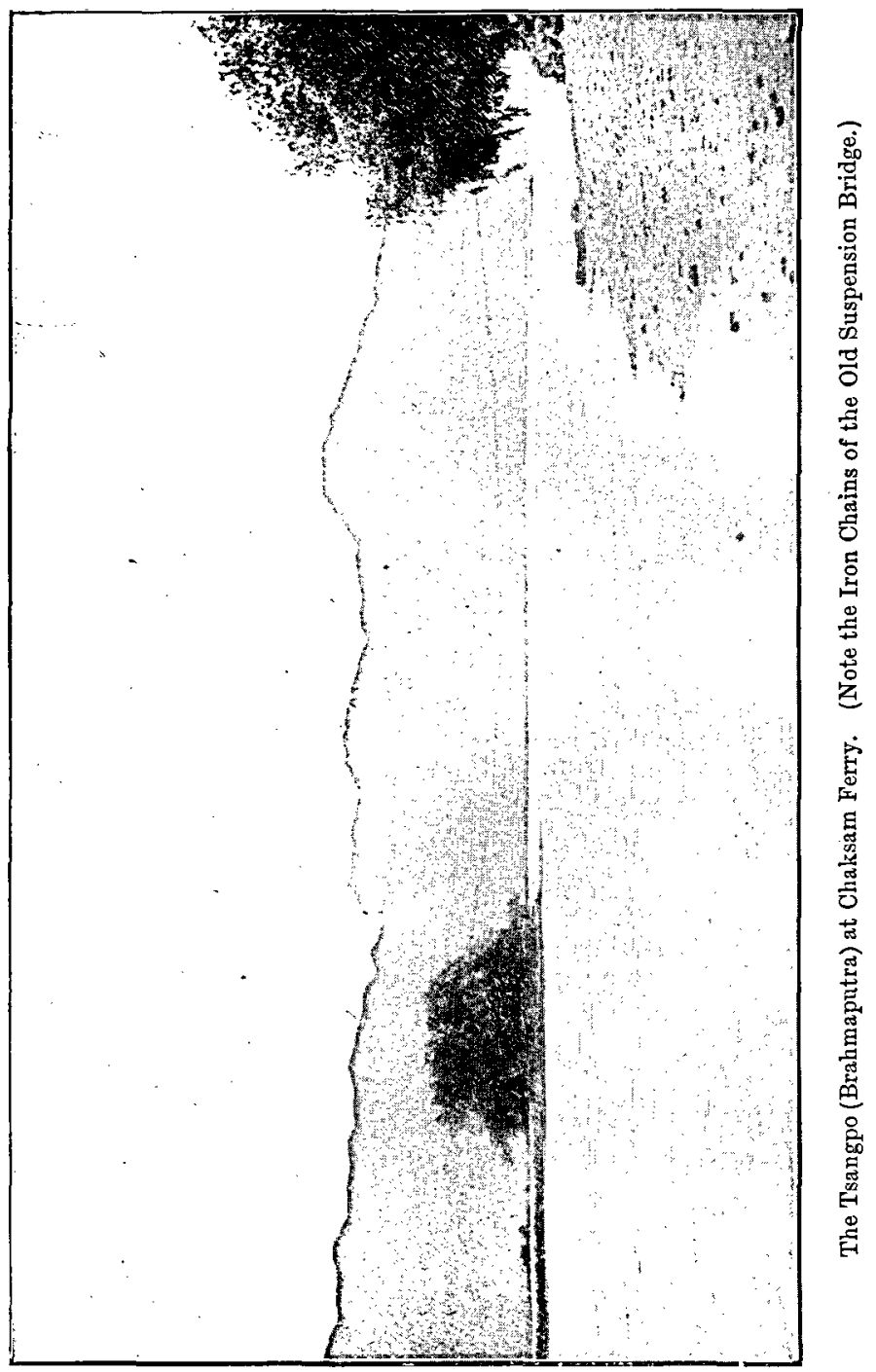

enced as the leading Lama in Lhasa. He was recognised as regent, and was the principal in the negotiations with me. But even he, pleasant, benevolent, genial old gentleman as he was, had really very little intellectual power, and but a small modicum of spirituality. In both he was very distinctly inferior to the ordinary Brahmin in India. $\mathrm{He}$ 
liked his little jokes, and we were always on the best of terms. But he was firmly convinced the earth was triangular. His intellectual attainments did not amount to much more than a knowledge by rote of prodigious quantities of verses from the sacred books. Discussion with him upon the why or the wherefore of things ended in bald quotations from the scriptures, and his religion chiefly consisted in ceremonial. The general run of abbots of monasteries and leading Lamas had even less to recommend them. One monastery at Lhasa contained no less than 10,000 monks, and another had 7000. But I do not think any one saw these monks without remarking what a degraded, nasty, sensuallooking lot they were. It is altogether a mistake to suppose that in Tibet is to be found a pure and lofty form of Buddhism. Buddhism and Chinese civilisation certainly have raised the rough tribes who, six or seven centuries ago, inhabited Tibet, into something very much higher than they were before these appeared. But intellectual and spiritual life is stifled by the rigorous monastic rule. All foreign ideas and individual originality have so far been trampled down. And the result is a people of inflexible rigidity, wholly unable to adapt themselves to altering conditions; and without any intellectual force or spiritual impetus. We sought for, but did not find, the wonderful Mahatmas, who would lead us to more lofty peaks of light and wisdom than ever we had trod before. And while I would not deny that Buddhism has done much to tame and civilise a barbarous race of demon-worshippers in Tibet, I would warn those who would look to Lhasa for any kind of higher intellectual or spiritual guidance, to seek nearer home for what they need. Imbued, as the Tibetans are, with much of that impassive contentment inculcated by Buddha, they are still, to all intents and purposes, demon-worshippers. Their religion is grotesque, and is the most degraded, not the purest, form of Buddhism in existence.

Happily we were able to entirely overcome that feeling of obstruction which the heads of the Tibetan Church had so far shown to outsiders. Through Mr. Wilton's influence with the Chinese officials, and Mr. White's connection of many years' standing with the Tibetan lamas in Sikkim, and his tactful suasion, we were able to gain access to all the monasteries and temples, and, before we left Lhasa, British officers went in and out with as little concern as they would to St. Paul's. I insisted upon having the Convention signed in the Potala, and in the finest hall in it, and once the lamas saw no harm resulted, and we invariably treated them with consideration, they entirely withdrew their obstruction, and when, just before leaving Lhasa, I paid a formal visit to the great cathedral called Jo Khang, I was surprised to find them actually pressing me to come inside the railings and walk round the magnificent image of Buddha-a freedom I have never had accorded me in any temple in India.

I fear I have not sufficient time to adequately describe these monasteries and temples. Outside they were solid and massive, though hardly beautiful. Inside they were weird and quaint, and sometimes grotesque. I carried away with me an impression of immense impassive 
figures of Buddha for ever gazing calmly and tranquilly downwards, of walls painted with grotesque demons and dragons, of highly decorated wooden columns and roofs, of general dirt and griminess, and of in-

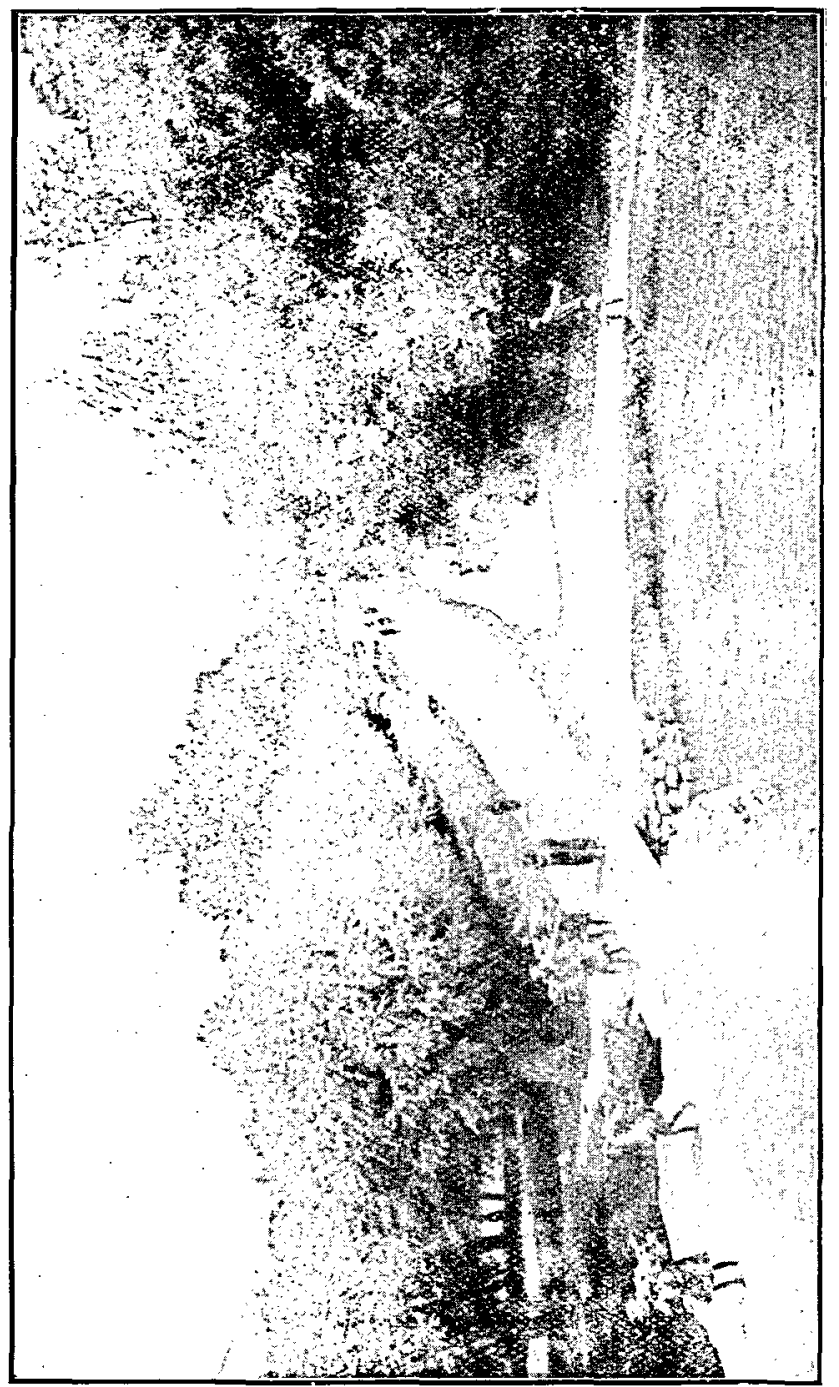

证

numerable bowls of butter burning night and day, as candles are burnt in Roman Catholic churches before figures of the saints.

Sooner than I could ever have expected, the Convention was signed, and we prepared for our return to India. Once business had been arranged, the Tibetans were all as happy as possible. No single person was responsible; each had had his say, and if blame had to fall on any 
one, it had to fall on all, and all equally. But in their heart of hearts they knew full well that they had got off remarkably cheaply, and they had indeed the grace to acknowledge this. On the morning of our departure the regent came down to our camp and presented images of Buddha to Mr. White and myself, as well as to General Macdonald. He thanked us for saving the monasteries and temples, and in presenting the image of Buddha to me, said, "When Buddhists look on this they put aside thoughts of strife, and think only of peace, and I hope that you, when you look at it, will think kindly of Tibet."

And certainly I left Lhasa with every kindly thought. It was a perfect autumn day; the sun was bright and warm. The valley was looking its prettiest in its autumn foliage. The entire council, with their secretaries, had come a mile down the road to offer us a farewell cup of tea and to wish us God-speed on our journey. Their last words were that they intended to keep the treaty and be friends with us in future. Our hopeless task seemed indeed to have been accomplished and good will to have been established.

And all that has happened since corroborates this impression. The council had willingly given permission for a party of officers to proceed through Shigatse up the Brahmaputra, to Gartok in Western Tibet, and then back to India by Simla. This important expedition was placed in charge of Captain Rawling, who two years ago had made a most successful journey in Western Tibet, while Captain Ryder, R.E., was in charge of the survey. These two officers, with Captain Wood, R.E., and Lieutenant F. M. Bailey as their assistants, have accomplished their arduous undertaking. Though accompanied by only an orderly each, and no armed escort, they have travelled through a thousand miles of Tibet, and been well received everywhere. Captain Ryder has surveyed 40,000 square miles of country, including the whole course of the Brahmaputra from Shigatse to its source, the Mansorawar and adjoining lakes, and the sources of the Indus and the Sutlej, and has proved beyond doubt that no higher mountain than Mount Everest lies at the back of the Himalayas. The party suffered indeed terribly from the cold, their thermometer registering $24^{\circ}$ below zero, but they crossed a pass 18,400 feet in height in December, and reached India in safety.

I trust, therefore, you will believe that the Tibet Mission has not been barren in geographical results, and that when you wish exploration work to be done, there are good and trusty men in India ever ready and willing to do it.

Note.-The illustrations accompanying this paper are from photographs taken by Lieutenant F. M. Bailey, 32nd Sikh Pioneers.-ED. S.G.M. 